\title{
Difficulties in Particular: Theological and Historical Context of the Anonymous Treatise "On the Common Nature and the Trinity"
}

\author{
Timur Shchukin \\ Associate Research Fellow at the Sociological institute of the Federal Center \\ of Theoretical and Applied Sociology of the Russian Academy of Sciences, \\ St. Petersburg \\ tim_ibif@mail.ru \\ Oleg Nogovitsin \\ PhD, Philosophy; Senior Researcher, Sociological institute of the Federal \\ Center of Theoretical and Applied Sociology, Russian Academy of Sciences \\ Associate Professor, Higher School of Social Sciences, Peter the Great St. \\ Petersburg Polytechnic University \\ onogov@yandex.ru
}

\begin{abstract}
The anti-Monophysitic anonymous treatise On the common nature and the Trinity was written in the 550-560s for the educational purposes in philosophy and theology. Therefore, its content was perceived in those days as something certainly traditional. It reflects theological discussions of its time, thus making feel the degree of complication of the current theological situation and the extent of mutual comprehension between the rival parties. The anonymous author normally keeps himself within the conceptual language of the late Neoplatonism, especially the school of Ammonius of Alexandria known by its interest to peripatetic instruments. The author himself is a Chalcedonian. When rejecting both "Nestorian" and "Severian" Christologies, he claims that the human nature became a constitutive element of the hypostasis of Christ (consisting of two common natures) and by no means an independent hypostasis. There are some similarities with the teaching of Leontius of Byzantium's Against the Nestorians and the Eutychians and Solution of the Syllogisms of Severus, whereas the present author is much more succinct, and his exposition is simplified. For instance, unlike Leontius of Byzantium, he does not distinguish the contexts, where the notions of nature and substance could be used differently; he does not state explicitly that the human nature
\end{abstract}


within the hypostasis of Christ is the common nature and not a particular nature. The latter term is used but never explained. The treatise is a curious witness of the relevance of an intra-Monophysite controversy for Chalcedonites.

\section{Keywords}

Christology - Chalcedonism - Monophysitism - Tritheism - particular nature Leontius of Byzantium - John Philoponus - Severus of Antioch

\section{1 \\ Introduction*}

The anonymous treatise published by Marvin Rashed under the title "On the Common Nature and the Trinity"1 has reached us in a single manuscript dated by tenth and eleventh centuries, which is preserved in the National Library of France (Paris. Coisl. 387) within a codex containing something like a selection of literature obligatory to be read for an average Byzantine scholar of that period. The selection consists of 15 texts; Filippo Ronconi divides it into five blocks. The first, to which our text belongs, includes the works on philosophical and theological issues. The second contains progymnasms, which are templates of the most primitive literature forms. The third represents rhetorical treatises, the fourth and fifth comprise epimerisms, that is, grammatical comments on classical antique texts, in particular, on Homer, and grammar books, for ex., the writing of Timothy of Gaza "On Syntax". ${ }^{2}$

* The reported study was funded by the Russian Foundation for Basic Research (RFBR), project number 19-011-00778, "Leontium of Byzantium and Patristics".

1 M. Rashed, "Un texte proto-byzantin sur les universaux et la Trinité," in: L'héritage aristotélicien: textes inédits de l'Antiquité, ed. by M. Rashed, Paris, 2007, pp. 345-377.

2 For the content of the corpus see in details: F. Ronconi, "Quelle grammaire à Byzance? La circulation des textes grammaticaux et son reflet dans les manuscrits," in: La produzione scritta tecnica e scientifica nel Medioevo: libro e documento tra scuole e professioni. Atti del Convegno internazionale, Fisciano-Salerno, 28-30 settembre 2009, ed. by G. De Gregorio and M. Galante, Spoleto, 2012, pp. 63-110, here 11-12. Michele Trizio has drawn attention to a notable coincidence: an eleventh century Byzantine philosopher John Italos in one of his lectures is referring to a representative of the Middle Platonism, Gaius, as an authoritative interpreter of Aristotle, while the similar references are also contained in the mentioned Parisian manuscript (M. Trizio, "A new testimony of the middle Platonist Gaius," GRBS, 53 (2013), pp. 136-145, here 137). It gives us another testimony of that the Parisian codex contains a compendium of knowledge which was actual during the period of theological and philosophical disputations of the second half of the eleventh century as well. 
The corpus' assemblage suggests that our anonymous treatise was used as a didactic text for exercises in philosophy and theology, therefore, at the turn of the first and the second millenia, its content was appreciated as something obviously traditional. With that, as we are going to expose in our article, it is one of the few surviving records of anti-Monophysite polemics of the middlesixth century. And it reflects the scope of theological matters which were revived by the early eleventh century not in the last turn because of the fact that the succession in the Byzantine intellectual milieu of the period was supported mainly with the help of the texts of the Fifth Oecumenical Council's period. $^{3}$ First of all, the influence of respective terminology is traced in the works of representatives of the "Neoplatonic renaissance", such as Michael Psellos and John Italos, who reproduced the logic of the sixth century in their writings. It is certain that the trails of this influence are found in the records of Psellos' and Italos' lectures. And if Michael Psellos relies on the texts of the sixth century in logical and philosophical treatises, John does it in his theological texts. E. g., the treatise of John Italos "On Two Natures", which is evidently directed against his contemporary Monophysites (Armenians), poorly reminds the wider writings of John Damascene and has more common traits with the anonymous text that we review here. ${ }^{4}$ Nevertheless, the question of the influence which the sixth century texts exerted on the eleventh century authors is still to find its researcher.

The doctrine on the common nature and the Trinity, represented in the treatise, is undoubtedly marked with diverse Byzantine theological fundamentals of the mid-sixth century. E. g., in connection with the anonym's critics

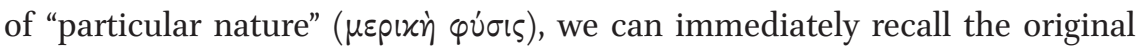
philosophical teaching on the particular nature by John Philoponus, who applied it in the context of trinitarian theology and Christology, while the interpretation of relations of "common" and "particular" nature is close to Leontius of Byzantium's conceptions. In the article, we will (1) examine the content of the treatise with its general outlook given below, and also make an attempt to ascertain its location within the respective theological disputations and the time when it was most likely could be written. With this aim, we will

3 P. Lemerle, Le premier humanisme byzantin: notes et remarques sur enseignement et culture à Byzance des origines au Xe siècle, Paris, 1971, p. 3. When the manuscripts became intensively fair-copied anew, the Byzantine culture primarily received at its disposal the package of the sixth century thought with all its merits and contradictions.

4 Иоанн Итал, Сочинения, редакция и предисловие Н.Н. Кечакмадзе [John Italos, Works, ed. by N.N. Kechakmadze,], Tbilisi, 1966, pp. 210-216. 
(2) analyze the historical sources of the terminology of the treatise and (3) estimate the character and origin of the argumentation used by the author.

\section{$2 \quad$ Content Review of the Treatise}

1. The author of the treatise consequently contraposes for the "natural things": (1) nature as something general, taken in an ideal sense, more precisely, as an abstract, as something abstracted from the real being, from singularities, and (2) singularities having a determined set of specialities and real being which is acquired in a hypostasis. On one hand, the "nature" is interpreted by the anonym as an abstraction in regard of the singular (p.1), ${ }^{5}$ which, nonetheless, does not testify his nominalism: it is only in the dimension of empirical cognition that the definition of being proceeds from the particular to the common (p. 2), and here he speculates as a peripatetic. On the other hand, the author of the treatise asserts that the "common nature" is individualized by the means of hypostatic idioms, i. e. in the ontological aspect, it is self-consistent in regard of the human knowledge proceeding from the particular (p.11).

2. The anonym criticizes the interpretation of the term "particular nature" ( $\mu \varepsilon \rho i x \dot{~ \varphi v ं \sigma \varsigma) ~ u s e d ~ b y ~ h i s ~ a n t a g o n i s t s ~(i n ~ t h e ~ p . ~} 5$ the same meaning is also

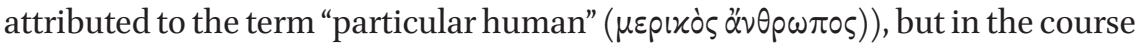
of polemics, he does not fully reject the very term. In some passages of the treatise dedicated to criticism of those who, in the anonym's conveyance, consider the "particular nature" as a self-consistent nature of a single individual, the author rejects this kind of interpretation, however, without any clarification of the precise sense in which his opponents use this term, just simply highlighting them as those asserting the same (pp. 5,12 ). At the same time, in the other places of treatise he uses the terms "particular nature" (p. 8), "par-

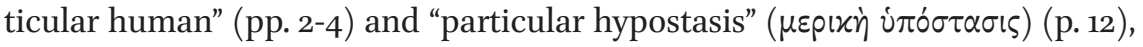
implying the humanity of Christ as well, to point at a single representative of the species, whom, however, it should correctly understand as an individualized $(\dot{\alpha} \tau 0 \mu \omega \theta \varepsilon \dot{\varepsilon} \nu)$ via the summation of hypostatic idioms "common nature" (pp. 2-8). In this aspect, the anonym approaches to Leontius of Byzantium, who, for the first time in the Orthodox tradition, in opposing the Monophysites and Nestorians, specifies the hypostasis in obvious terms for Christology as a real individual consisting of common nature and hypostatic idioms that individualize it. In the context of deployment of such a definition, he even uses, on

5 Here and forth, to indicate the places from the treatise under our research and for the purpose of quotation we will apply its division by paragraphs performed by M. Rashed. 
one occasion, the notions of "individual nature" ( $\left.\dot{\eta} \dot{\varepsilon} v \dot{\alpha} \tau \dot{\tau} \mu \omega \varphi \varphi v^{\prime} \sigma \varsigma\right)^{6}$ and "this

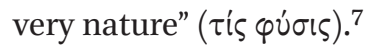

As for the second meaning of the term "particular nature" formulated by the anonymous author, as well as for the above mentioned terms of the same conceptual range, we should underline that, from his point of view, the idioms are inseparable from the hypostasis in reality. Nevertheless, taking this into consideration, it is possible to make cautiously a distinction in the order of use of these terms by the anonym: when pointing at the reality of hypostatic being, he applies the terms "particular human" and "particular hypostasis", while for him, the "particular nature" is probably an outcome of abstracting of hypostatic idioms and "common nature" with its own idioms within the determined individual (p. 7-8). ${ }^{8}$ The intellectual character of particular nature is emphasized by that the cognition of the particular within the individual things is - "through abstracting the hypostatic idioms" - a prerequisite to cognize the common nature of these things, differently from God, wherein the contemplation of the common precedes the cognition of hypostases through the faith

6 Leontius of Byzantium, Epilyseis, 1; Leontius of Byzantium. Complete Works, ed. and tr. by B.E. Daley [thereafter ed. Daley], Oxford, 2017, p. 270.16.

7 Leontius of Byzantium, Epilyseis, 1; ed. Daley, p. 272.6. According to Richard Cross, who refers, inter alia, to this place in his interpretation of "Epilyseis", Leontius of Byzantium, prior even

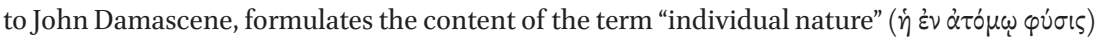
both in general ontological and, particularly, in Christological context. In this version, the hypostasis shall be interpreted as something communicating the individual nature of a thing (taken as a summation of the common nature and hypostatic idioms) the real existence within an individual. At this point, the presence of individual nature in the reason shall be understood as comprehension of reality of its hypostatic being. From this perspective, John Damascene, while relying on the intellectual tradition which ascended to the works of John of Caesarea and Leontius of Byzantium, through Leontius of Jerusalem and Maximus the Confessor, gives a strong definition to this doctrine having been shaped in the course of the Christological disputations of the sixth century. See: R. Cross, "Individual Natures in the Christology of Leontius of Byzantium”, JECS, 10.2 (2002), pp. 245-265, here 252. For explicated interpretations of the treatise in this clue, see also D. Krausmüller, "Making Sense of the Formula of Chalcedon: the Cappadocians and Aristotle in Leontius of Byzantium's Contra Nestorianos et Eutychianos," VC, 65 (2011), pp. 484-513. Dirk Krausmüller believes that Leontius' "enhypostaton" correlates with the "authypostaton" of Aristotle like substance and substantial idioms, separated from it, and it is "clearer" or more profound form of individual being than the first substance. Some notes on Krausmüller's interpretation: T.A. Shchukin, "Identity in Difference: Substance and Nature in Leontius of Byzantium's Writings," Scr, 12 (2016), pp. 308-321.

8 "7. It shall be understood that in regard of the natural things, we cognize the particular and thus ascend to the common. Proceeding from Peter and Paul, through abstracting the hypostatic idioms, we cognize the common and universal human. $<\ldots>8$. There is an endless number of idioms of particular natures in the human, for example: Peter is a fisherman, son of Jonah, leader of apostles: while the universal human has a smaller number of idioms". 
(p. 7). Thus, in the polemical context, he rejects the relevance of the term "particular nature", and uses it in a positive sense of heuristic abstraction only beyond the polemics.

3. In the treatise, the distinction between the common and the singular is suggested by a standard definition of peripatetic logic: singularity shall not be predicted to the common nature, but the common "presents" ( $\dot{\varepsilon} \tau \iota)$ in the singular, as the anonym says. In fact, he asserts: “...the nature is present ( $\dot{\varepsilon} \sigma \tau)$ in

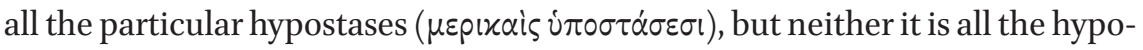
static singularities, nor the particular hypostases are predicated to it. For we

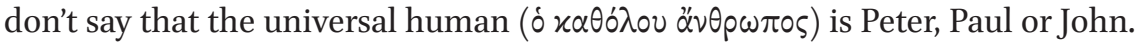
As a matter of fact, once you said that the universal human is present $(\dot{\varepsilon} \sigma \tau \iota)$ in Peter, it would have appeared that the universal human is Peter, Paul or John, which is nonsense" (p.12). It should be assumed that here he uses the term "nature" in relation to the "common nature of man" and understands it as a real entity, but it is real in a different sense than the reality of individualized hypostatic properties of particular human individuals (hypostases), which are given to human contemplation in this world. In such sense, the real nature of "universal human" "is present" in all particular human hypostases, yet it itself is not these hypostases and in the given sense is not already "present" in them. In the sphere of the "intelligible", the anonym represents easily both the human and the divine as two common natures or substances. On one hand, he treats them only in a logical way (otherwise they would be real hypostases), but, on another hand, he directly affirms that there is no contradiction between contemplation and existence, therefore, the common natures (both of God and human) exist by themselves as intelligible, with that the divine nature is called by him "supersubstantial" (p. 11) As a consequence, the ontological state of both natures remains indefinite in strong terms, as well as the correlation between the common nature and the particular hypostasis.

Nevertheless, the terminological incertitude is not an invincible obstacle in understanding the dogmatical context of the anonym's thought on correlation of common and particular in being. Even in the very beginning of the treatise he appeals to an example from the area of Christology for explanation. When he asks a question: "Once the universal human, or the humanity, is incorporeal, how, then, did Christ - being incorporeal - accept a body? For it is impossible that the incorporeal accepts a body" - he would make a decisive answer: "When I say that the Son of God has accepted humanity, I observe this humanity as incorporeal and common, however, when I contemplate the humanity as individualized, I affirm that it is a body and recognize that it is a particular hu-

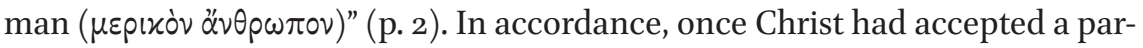
ticular human hypostasis, he would have become of two hypostases, what 
could testify the Nestorianism when accepted (p. 3), as well as a refusal of the common nature in favor of the particular directs, by the anonym's thought, to the concession to that the humanity has not been accepted by Christ (p. 10). In other words, Christ accepts in his divine nature the common nature of a human, "the universal human which has been individualized within himself and become a part of his [special] hypostasis" (p. 3). Christ is both God and a human, but he has got a single hypostasis wherein the nature of both of them is individualized.

4. On the assumption of the given above interpretation of correlation of common and particular, in his descriptions of the mechanism of "embodiment" of nature into hypostasis, the author is constantly emphasizing that a separate singularity doesn't contain the common nature taken separately, for the last is not identical with all the hypostases it dwells within (pp. 6, 12), but by that, the very same nature is presented in all the singularities (pp. 5,12 ). In transition from Christology to the created things, he explains his thought as follows: "When you say that Peter is a human, what human do you predicate: a common or a particular one? Neither. This is not only a universal and common human, and not only a particular human, but the one that is observed as universal just in the reason, while being present in Peter individually" (p. 4). ${ }^{9}$ This attitude, in spite of all the detriments of the author's way of expression, appears as a basis of dogmatical critics of adversaries throughout the treatise. The anonym asserts with permanent obstinacy that the individualization happens due to augmentation of idioms to the common nature as opposed to what all those who misuse the term "particular nature" say (pp. 2-6, 12), however, he gives no clarification on this account. Thus, as a result, while he uses in the pp. 7-8 the term "particular nature", after his own manner, to significate the summation of separate hypostasis' definitions, in the pp. $2-6$ he criticizes the use of the given notion, and in the p. 12 rejects the very term "particular nature". To deny that the common nature is real within the individuals of the same species, according to the anonym, leads to false conclusions in Triadology as well. In the p. 10, he accuses in tritheism on this basis those who, as implied, consider the nature of God only proceeding from the reality of the separate Persons and, further, in p. 12, he states that once we represent the divine nature, or deity, as one, we will get in the conclusion not three hypostases of one God, but a tetractide of particular natures.

Essentially, the author's major problem is in the absence of any logical nexus or any element which would allow to distinct an abstract of particular

9 This phrase has a direct parallel in the treatise of Leontius of Byzantium (Leontius of Byzantium, Epilyseis, 1; ed. Daley, p. 272.6-7). 
nature from a hypostasis. He does not enunciate (like Leontius of Byzantium did) that the very being as a hypostasis, a "logos of self-consistent being" ( $\dot{0}$ $0 \hat{v}$

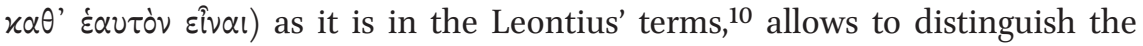
summation of common nature and hypostatic idioms represented in mind, i. e. "this-very-nature", and the hypostasis as an expression of one and the same, and simultaneously distincts in itself in the aspects of thought and existence, reality. The anonym just restricts himself by a reference to that the "human Peter" is a human "that is observed as universal just in the reason, while being present in Peter individually" (p.4), and that in this individual being, or hypostasis, one can intellectually distinguish the particular idioms which individualize the common nature, along with this very nature with its own idioms common to all individuals (p. $7-8$ ).

5. It seems to be important for the anonym to distinguish the common nature within the Trinity and created things. The common deity is understood as something real in the treatise. Probably, it is namely this that the anonym indicates on when affirming that, differently from the created individualities, which are intelligible prior to their common nature, it is cognized prior to its hypostases. This is argued by that in the beginning, the people recognize "one God" and only after that (upon Christ's coming) - "the Father, the Son and the Holy Spirit" (p. 7). This argument supposedly refers to the historical knowledge: the Jews were the first to know God and only thereafter the advent of Christ reveals him to the world in three Persons at once. Unlike the cognition of created things, the divine unity reveals itself to a Christian as the Trinity beyond the way of thought habitual for the human, which goes from particular to common: "Seeing the deity as one light, we divide then the hypostases by sole faith" (p. 7). The abundance of definitions (idioms) of divine nature - the

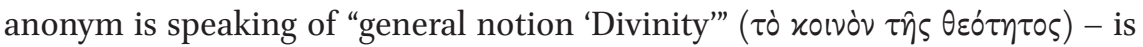
strengthened by the fact that an infinite number of idioms is proper to it, and "a minimum number of hypostatic idioms is enumerated: the Father is unbegotten, the Son is begotten and the Holy Spirit is proceeding", while there are infinitely many idioms that are proper namely to the singularities on the level of creation, and "the universal human has a smaller number of idioms" (p. 8). The common nature of God, in accordance with the anonym, is a source of unity of the hypostases which is ensured by the unity of glory, will and energy of this nature, whereas, for the created hypostases, there is no way to perceive common nature as a specific power holding their unity (so that we could conditionally replace Adam, the first created human, by any other one). In God, the nature of the common unifies, while in the created world 
it serves as a common base of various distinctions of the different, i. e. ontological diversification of the common order of the being by genera, species and individuals (p.9). Finally, the term "superessential substance" (i $\pi \varepsilon p o v ́ \sigma ı \varsigma$ ov $\sigma^{\prime} \alpha$ ) makes evidence that for the anonym, the deity is excluded from the logic functioning in the created world, and in this sense it bears another reality due to that it does not participate in the world of the intelligible by the model of ontological division of the being. As the author of the treatise denotes: "It might be thought also in itself, and not among other things" (p. 11). It is the discovery of the strength of unification which is inconceivable for the created being and included within the common nature of the divine that allows to recognize the hypostases in their idioms, that is, relations of being unbegotten, being begotten and procession (pp. 8-9).

\section{$3 \quad$ Origin of the Treatise's Terms}

As a whole, the conceptual language of the treatise is based on intellectual groundwork of the late Neo-Platonism, especially that of Ammonius' of Alexandria school with their sufficient interest to peripatetic range of tools. This is witnessed by terminological apparatus used by the author. In particular,

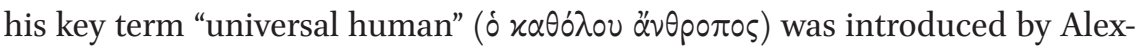
ander of Aphrodisias, ${ }^{11}$ then accepted by Ammonius ${ }^{12}$ and by his disciple, John

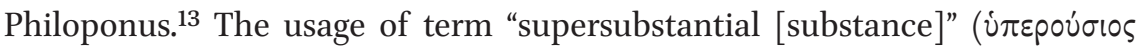
[ov $\left.\left.\sigma^{\prime} \alpha\right]\right)$ could be ascribed to the influence of "Areopagitics", 14 once another signs of such influence could be traced in the text of the anonymous commentary. This term ascends rather to Alexander of Aphrodisias. ${ }^{15}$ It is used by

11 Alexander of Aphrodisias, In Metaphysica, 6.10 et alii; Alexandri Aphrodisiensis in Aristotelis metaphysica commentaria, ed. by M. Hayduck (CAG, 1) [thereafter ed. Hayduck], Berlin, 1891, pp. 509 et passim.

Ammonius Hermiae, In Categorias, 5; Ammonius in Aristotelis categorias commentaries, ed. by A. Busse (CAG, 4/4) [thereafter ed. Busse], Berlin, 1895, p. 38. John Philoponus, In Analytica Posteriora, 2.19 et alii; Ioannis Philoponi in Aristotelis analytica posteriora commentaria cum Anonymo in librum II, ed. by M. Wallies (CAG, 13/3) [thereafter ed. Wallies], Berlin, 1909, p. 438 et passim. sius Areopagita. De divinis nominibus, ed. by B.R. Suchla (PTs, 33), Berlin-New York, 199o, p. 108. 
Proclus ${ }^{16}$ and John Philoponus. ${ }^{17}$ The conception of deity as substance, which is not a subject of being in the sense that it is not a subject of accidentals and likewise is not a subject for necessary definitions of substance (genus, species, distinctive feature), used by the author of the treatise, also ascends to Ammonius of Alexandria, in particular, to his commentary on "Categories" of Aristotle. ${ }^{18}$ The term "individualized" ( $\left.\alpha \tau \sigma \mu \omega \theta \varepsilon v\right)$ is found at least in the works of Pseudo-Simplicius in the meaning of particular eidos which stands apart within more common eidos. ${ }^{19}$ The term "particular nature" is specific for John Philoponus. ${ }^{20}$ The very logic of "individual as the most particular nature", that is, an individuality taken as an abstraction without accentuation of individualizing features with the only definition through separation from the common nature, is also found in the texts of Ammonius. E. g., the last ascribes to the soul separated from the body the being beyond any intelligent definition, beyond any real definitiveness, the pure intelligent and intelligible being. ${ }^{21}$

At the same time the language and logical steps of Ammonius' school were a shared range of tools for different (often contrary in views) theological trends of that time. Severus of Antioch studied philosophy in Alexandria right at the time (485-487) when Ammonius lectured there (470-517 (527?), 22 and John Philoponus was the most brilliant of Ammonius' disciples. But even such a prominent representative of Chalcedonite party as Leontius of Byzantium used freely and thus creatively, the groundwork of Alexandrian Neo-Platonists. ${ }^{23}$

16 Proclus, Institutio Theologica, 115; Proclus. The elements of theology, ed. and tr. by E.R. Dodds, Oxford, 1977, pp. 100, 102.

17 John Philoponus, De opificio mundi, 1.17; Joannis Philoponi de opificio mundi libri VII, ed. by W. Reichardt, Leipzig, 1897, p. 42.

18 Ammonius Hermiae, In Categorias, 5; ed. Busse, p. 37.

19 Simplicius, De anima, 3.4; Simplicii in libros Aristotelis de anima commentaria, ed. by M. Hayduck (CAG, 11), Berlin, 1882, pp. 217-218.

20 John Philoponus, In Analytica Posteriora, 1.2; ed. Wallies, p. 25; John Philoponus, In Physica, 1.1, 2.1; Ioannis Philoponi in Aristotelis physicorum libros octo commentaria, 2 vols., ed. by H. Vitelli (CAG, 16-17), vol. 1, Berlin, 1887-1888, pp. 18, 201.

21 Ammonius Hermiae, In Categorias, 5; ed. Busse, p. 37.

22 About the early period of Severus' life see: P. Allen, C.T.R. Hayward, Severus of Antioch, London-New York, 2004, pp. 6-11. It should be also reminded that a friend and biographist of Severus - Zacharias the Scholastic - was undoubtedly Ammonius' disciple.

23 The closeness of Leontius to Ammonius was so noticeable that their texts are even compiled together in some manuscripts, to what Peter Junglas paid attention (P. Junglas, Leontius von Byzanz. Studien zu seinen Schriften, Quellen und Anschauungen, Paderborn, 1908, pp. 13-15). It was him who also marked several terminology intersections - not all of them, for it was not his task - between the pagan and Christian thinkers. E.g., he revealed the parallel between the term $\dot{\alpha} \pi \lambda \hat{\alpha} \sigma \omega \dot{\omega} \alpha \tau \alpha$ ("simple bodies") used by Leontius and Ammo-

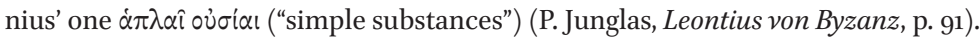


As a result, on the grounds of researching the specificity of the teaching contained in the treatise and the genesis of its terminology, it is possible to assert with reasonable confidence that the problematic area of the anonym's concern ascends to the sixth century theological controversies. Though it is not satisfactory to get an answer on the question in which is the particular episode of the polemics around the Chalcedonian Council's definitions where the anonymous author could have participated in, whose side could he have supported and in what exact moment could he act. Nevertheless, in our view, an analysis of the polemical argumentation represented in the treatise would in a certain way deliver the answer to it.

\section{The Anonym's Arguments Against the Supporters of Particular Nature and the Time of Writing the Treatise}

There is nothing obscure about the "political" attitude of the author: he is a supporter of Chalcedon Council and a principal adversary of Nestorians and Monophysites. While unambiguously rejecting the "Nestorian" discourse of "Christ of two hypostases", the anonym suggests that the human nature becomes a part of Christ's hypostasis but not a self-consistent hypostasis: "The one who asserts that the Son has accepted not the universal human, or the humanity, but a particular human implies that he has accepted a sole hypostasis and thus appears a Nestorian confessing Christ as composed of two hypostases. Due to that, it should be said that Christ has accepted the universal human which has been individualized within himself and becomes a part of his [special] hypostasis, but not the hypostasis, since the hypostasis emerged not prior to him" (p. 3) The Nestorianism is the sole heterodox doctrine mentioned in the treatise by its traditionally accepted name. Here the anonym builds an argument so that he could accuse the supporters of "particular nature" in heresy. ${ }^{24}$ While holding in mind the condemnation of Nestorianism by both Chalcedonites and Monophysites, we can suppose that by using so toughly a

24 This argument is similar to those specific for Chalcedonite Christology within Nestorian and especially Monophysite disputations. E. g., this kind of argumentation in close formulations is intently considered by John Philoponus in "Arbiter": John Philoponus. Arbiter, 7; John Damascene, De haeresibus, 83.179-195; Johannes von Damaskos "Liber de haeresibus". Die Schriften des Johannes von Damaskos. Bd. Iv: Liber de haeresibus. Opera polemica, ed. by B. Kotter (PTS, 22) [thereafter ed. Kotter], Berlin, New York, 1981, p. 55. Leontius of Byzantium also polemically addresses this problem field in diverse contexts in "Epilyseis" due to the Monophysite-specific word usage: "For where is the existence of another one before the Union - I mean humanity - so that you can teach about what is after the Union?" (Leontius of Byzantium, Epilyseis, 7; ed. Daley, pp. 292.31-294.1). 
polemic method he orients himself within the polemics actual for his time. It is most probable that here we deal with the debates on the state of the notion "particular nature" in Christology initiated in the 50-s of the sixth century by the respective doctrine of John Philoponus.

The doctrine of John Philoponus on "particular nature" marked a new stage of Monophysite disputations after those of Severus. By the term "particular nature", he thought the nature in logical subordination to the common nature as its example abstracted from accidentals but not coinciding with it in its real being. ${ }^{25}$ As applied to Christology, it could mean that for him in the unity of Christ's hypostasis, two particular hypostases, divine and human, were joined together. Severus of Antioch has also promoted a specific teaching on particular nature elaborated as a Christological case study: we speak about a conception of not self-consistent hypostasis which is a pure individuality, while, existing only due to being in another self-consistent hypostasis. ${ }^{26}$ Severus supposed that it is not the substance of God that joins with the humanity (the substance

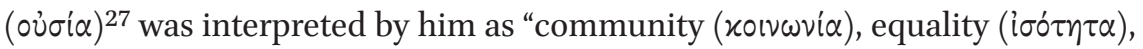

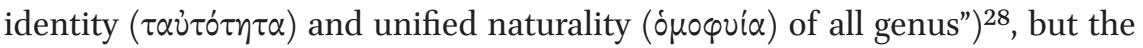
nature only or, what is the same in Severus' terms, hypostasis of the Word. The humanity which accepts the Word is not common human substance, but the nature or hypostasis differs from the hypostasis of Word in that it is not self-

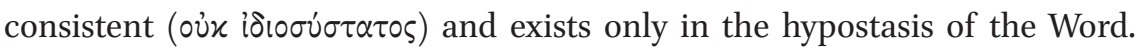
But whereas Severus used the elements of Alexandrian philosophical system in order to articulate the doctrine (already traditional for Monophysitism) on individuality of human nature (of hypostasis) in Christ, it was the very philosophical system from which John Philoponus deducted the Christology. At the same time, as an almost momentary reaction on the Severus' doctrine, there emerged a studious conception of Leontius of Byzantine on nature as the second essence with which hypostatic idioms join and which becomes

25 See: U.-M. Lang, John Philoponus and controversies over Chalcedon in the six century. A Study and Translation of the "Arbiter", Leuven, 2001, p. 50.

26 Severus of Antioch, Contra impium Grammaticum, Or. 2.4; Severi Antiocheni liber contra impium Grammaticum. Oratio prima et orationis secundae quae supersunt, ed. by I. Lebon (CSCO, vol. 112; Scriptores Syri, t. 59) [thereafter tr. Lebon], Louvain, 1938, pp. 58-64.

The work of Severus of Antioch "Against the Impious Grammarian", which contains the doctrine on not self-consistent hypostasis, exists in Syriac translation from Greek, and because of that, the Greek equivalents of terms are hypothetic.

28 Severus of Antioch, Contra impium Grammaticum, Or. 2.1; tr. Lebon, p. 47: "nomen 'homo'... substantiae est significativum, significans communitatem et coaequationem et identitatem atque connaturalitatem totius generis". 
enshrined within the reality through the being-as-itself of the hypostasis. ${ }^{29}$ The clash of these theories is most vividly manifested in the late Leontius of Byzantium's treatise "Solution of the syllogisms of Severus", where he proposes a doctrine on common nature as individualized through idioms, "this-very-

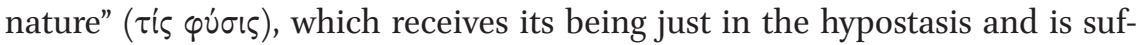
ficiently distinctive from the particular nature ( $\mu \varepsilon p \mid x \dot{\eta} \varphi v \dot{\sigma} \sigma \varsigma$ or $\mu \varepsilon p$ both Severus' and John Philoponus.' ${ }^{30}$

In these disputations, the anonym takes a position similar to that of Leontius of Byzantium, but, unlike him, does not clarify the way whereby the particular and the common in the hypostasis correlate and accept the reality of individual. He polemizes supporting the reality of being of the common nature in the hypostasis through the individualization by the means of hypostatic idioms and provides this teaching in the course of criticizing the notion of "particular nature". Then the anonym's arguments look often rather formal and arbitrary: while criticizing his opponents, he does not come into details of their statements and, as a rule, modifies the sense of the terms they use in a polemically convenient mode. As we have already noted, in the course of critics, he utilizes the term "particular nature" once in the initial meaning of an individual as solely actual being (the sense which John Philoponus attributes to it), once in the meaning of an individual identical with the notion of "common nature" in his actuality, i. e., in a contrary way (p. 6, 12). Unsurprisingly, this way of arguing is fraught with logical contradictions.

This circumstance is clearly revealed in the case of advancing the most efficient argument: those taking the particular nature for the sole actuality of an individual do not understand that then a perdition of a single representative of the species would entail a loss of the entire species. The versions of this argument are present in pp. 6 and 12. We will quote both of them: (1) "And another absurdity turns out for those who affirm that Peter is predicated by a particular human. For if the individualized universal human is not predicated

29 Richard Cross formulates the doctrine this way: "An individual nature is a universal nature considered along with a (unique) collection of universal accidents. (Contrast the case of particular natures, which are the instances of a universal in abstraction from their accidents" (Cross, "Individual Natures", p. 252). Cross believes that Leontius has introduced this conception in "Epilyseis". In our opinion, however, it is not like this, and it is acceptable to speak only of modifying the range of terminology tools in comparison with the earlier treatise "Against the Nestorians and Eutychians" (see: T.A. Shchukin, "Identity in Difference: Substance and Nature in Leontius of Byzantium's Writings," Scr, 12 (2016), pp. 308-321).

30 Leontius of Byzantium, Epilyseis, 1; ed. Daley, p. 272.6-7: "Acephalos: Did he assume this very [particular] nature ( $\tau \imath \dot{\alpha} \varphi \dot{v} \sigma v)$ ? Orthodox: Yes, but one which is the same as the species". 
to Peter, so when Peter perishes, and his nature perishes and all the people should die, which is nonsense" (p. 6); (2) "To those asserting that there exists a particular nature, we will say that the nature of humanity, which is in Peter is either the same as in Paul or differs. If it differs, then Peter and Paul will be of different natures, while if it is one and the same, then once Peter perishes, the nature present in him will not perish (

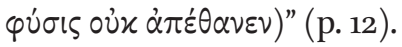

In both cases the anonym is most likely to use this argument against Monophysites with their "particular nature". As for the content, however, the strength of the given argument directly concerns the only one of all close in time to the above mentioned polemical context positions, namely the position of the Chalcedonites (similar in their views with John of Caesarea), who were inexact in expression and implicitly identified the common and the particular in individual, being subject to Severus' critics in this point. ${ }^{31}$ They, although, did not use the term "particular nature". What for Monophysites, and first of all John Philoponus, the exposed argument could have been meaningful for them once they made such an identification, but it does not match their teaching.

This argument coincides in its structure with that of Severus contra John of Caesarea. The difference is in that once the anonym is speaking of the created hypostasis, Severus asserts that the equation of the common nature with individual would have led to embodiment of God's Word into all the humans. As by Severus, "[John says that] the bodies of all people belong to the same genus and are consubstantial, so we have to conclude that all of humanity is

$31 \quad$ The doctrine of John of Caesarea is restored by the excerpts that Severus cites in the treatise "Against the impious [presbyter John of Caesarea the] Grammarian" (usually dated 511 A. D.). John of Caesarea has proposed to count the human substance of Christ distinct from his hypostasis and identical with the nature of all humans. Nevertheless, he has not elaborated any doctrine on how does this common substance/nature actualizes in specific historical Jesus. According to Severus, "this Sophist [John Grammarian] asserts ... that Christ is known in two substances, that is, in what denotes genus: in the common divinity and the community of all mankind" (Severus of Antioch, Contra impium Grammaticum, Or. 2.17; tr. Lebon, p. 112: "Dicit iste sophists... ut Christus agnoscatur in duabus substantiis, id est, in significationibus genericis, in divinitate collectiva et in communi entitate totius humanitatis"). As it is possible to estimate, for John the Grammarian, the substance present in the hypostasis (in the sense of real individual) is identical with the substance as itself. The point of difficulty for John the Grammarian of Caesarea was in that he did not provide any logical step between the common (substance devoid of individual features) and individual (hypostasis), that is, he did not shape a notion of substance with the individual features adjoined thereto, which could allow him to describe the presence of substance in the individual. On polemics between Severus and John of Caesarea see: A. Grillmeier, T. Hainthaler, Christ in Christian Tradition, vol. 2.2, tr. by J. Cawte and P. Allen, London-Louisville, KY, 1995, pp. 52-67. 
woven into the Word and folded with him". ${ }^{32}$ However, the argument identical by form to the anonym's version is discovered namely in the text of John Philoponus. He insists that the identity of common nature and individual would have led to perdition of the entire species along with a loss of its single member, and only the fact that each individual possesses a particular nature distinct from the common nature of the species keeps the species safe in spite of dying of the individuals participating in it. John Philoponus varies the general form of this argument both in Christological, in reiterating the Severus' version, and in Triadological contexts when asserting that the identification of common and particular nature would mean an embodiment of the Father and the Holy Spirit. The author of the treatise has probably known this Philoponus' argumentation (it is represented in the famous Philoponus' Christological treatise "Arbiter" whereby he tried to reconcile Severians and Chalcedonites) ${ }^{33}$, but could not reproduce it without explanations, for he used the given argument to prove the impossibility of the notion of "particular nature" to the being of individual, that is, the vision contrary to what Philoponus stood for. We provide the summary of respective premises and conclusions as Table 1.

TABLE 1 A Summary of Key Premises and Conclusions by Anonym and John Philoponus

\begin{tabular}{|c|c|c|}
\hline Anonym, p. 6 & Anonym, p. 12 & John Philoponus \\
\hline $\begin{array}{l}\text { Particular nature exists, } \\
\text { but it is identical with } \\
\text { common nature }\end{array}$ & $\begin{array}{l}\text { Particular nature does not } \\
\text { exist, common nature is } \\
\text { the same in individuals of } \\
\text { one species, but it is not } \\
\text { identical with hypostasis }\end{array}$ & $\begin{array}{l}\text { Particular nature exists, but } \\
\text { it is not identical with } \\
\text { common nature }\end{array}$ \\
\hline $\begin{array}{l}\text { Death of a single human } \\
\text { entails death of all } \\
\text { humans }\end{array}$ & $\begin{array}{l}\text { Death of a single human } \\
\text { does not entail death of all } \\
\text { humans }\end{array}$ & $\begin{array}{l}\text { Death of a single human } \\
\text { does not entail death of all } \\
\text { humans }\end{array}$ \\
\hline
\end{tabular}

If in p. 6 the anonym applies the considered argument in a subjunctive way as a hypothetical syllogism: on the condition of identification of common and particular natures, the death of Peter necessarily entails the death of all humans, in p. 12 he represents it similarly with Philoponus: the humans will not die with the death of a single man. For the anonym, this conclusion

\footnotetext{
32 Severus of Antioch, Contra impium Grammaticum, Or. 2.17; tr. Lebon, p. 116: "corpori omnium hominum est homogencum atque consubstantiale, ideo censebimus implicatam esse Verbo atque cum Ipso compositam totam humanitatem". 
immediately flows out of that the common nature of the human is the same in individuals. On the contrary, for Philoponus it is verified by that the common nature is actual only as a particular nature of a separate individual.

The author of the treatise is attempting to adjoin this conclusion to the opposition of commonness and diversity of the natures of individuals. "The nature of humanity, which is in Peter is either the same as in Paul or differs. If it differs, then Peter and Paul will be of different natures, while if it is one and the same, then once Peter perishes, the nature presenting in him will not perish" (p. 12). That means, once the particular natures are distinct, there exist as many natures as there are individuals (Peter and Paul appear of different natures). On the contrary, once Peter and Paul are of the same nature, the death of Peter (or Paul) would not lead to perdition of all humans. It is right only if we correctly understand the nature of common in individual: "For the humanity that

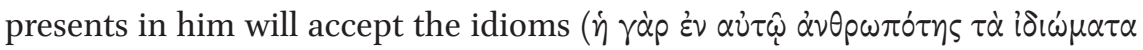
$\delta \varepsilon \dot{\xi} \xi \tau \alpha l)$ and is called not nature but hypostasis".

This passage is hard to be interpreted consequently. It is not easy to suggest that the anonym establishes the direct logical interconnection between the judgment on difference of nature of individuals belonging to one species, i. e., in fact, their not pertaining to one species, as a consequence of admitting the particular nature, and the judgment on that the refusal of understanding the individual as the common nature individualized by hypostatic idioms logically leads to perdition of the entire nature along with perdition of any individual representing it. Such a conclusion does not formally flows out of proof of nature difference of the individuals of one species with the admittance of particular nature. It is possible only by identifying the common and the particular natures in a single individual. As noticed from the text of p.12, the anonym does not make this assumption directly.

The same latent contradiction is repeated in transition from p. 5 to p. 6 . In p. 5 , the anonym asserts that to admit the "particular nature" leads to differentiation of nature of individuals, for there is no way to recognize a "human" ( $\left.\alpha^{\prime} \nu \theta \rho \omega \pi \circ \varsigma\right)$ (Peter or Paul) as a "simply human" ( $\left.\dot{\alpha} \pi \lambda \hat{\omega} \varsigma \stackrel{\alpha}{\alpha} \nu \theta \omega \omega \pi \varsigma\right)$, while in p. 6 he says that "for if the individualized universal human is not predicated to Peter, so when Peter perishes, and his nature perishes and all the people should die, which is nonsense" He does not represent a logical basis for the necessity of this conclusion here either. Essentially, the author of the treatise simply insists on that the reader should take into account the following reason: those who do not understand the real state of things concerning individualization of the common nature, introduce the notion of "particular nature" and mingle this concept with the notion of common nature. 
There are some clarifications on the conditions of such mixture of common and particular in p. 12, right after the formulation of disputable argument: "if it is one and the same [common nature in Peter and Paul], then once Peter per-

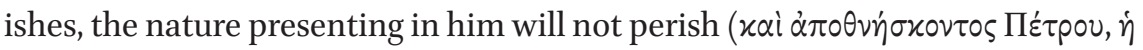

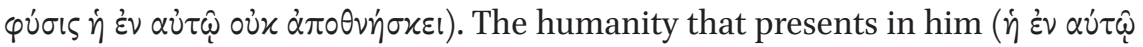
$\left.\dot{\alpha} \nu \theta \omega \pi \delta^{\prime} \tau \eta \varsigma\right)$ will accept the idioms and is called not nature but hypostasis. As nature is a name of proper and common to all. It needs to be known that the nature is present $(\dot{\varepsilon} \sigma \tau \iota)$ in all the particular hypostases ( $\mu \varepsilon p i x \alpha i \zeta ~ i \pi \circ \sigma \tau \dot{\alpha} \sigma \varepsilon \sigma l)$, but neither it itself is not all the hypostatic singularities, nor the particular hypostases are predicated to it. For we don't say that the universal human $(\delta$ $x \alpha \theta \dot{\partial} \lambda$ ov $\left.\alpha^{\prime} \nu \theta \rho \omega \pi \circ \varsigma\right)$ is Peter, Paul or John. As a matter of fact, once you said that the universal human presents ( $\dot{\sigma} \sigma \iota)$ in Peter, it would appear that the universal human is Peter, Paul or John, which is nonsense. Who declares the particular nature because Peter is nature, as well as Paul, says nonsense. For if the nature is present $(\dot{\varepsilon} \sigma \tau)$ in them, it is one and the same in both of them". As follows from the text, the common nature is individualized through the idioms and, as being individualized, appears a real existing individual, i. e., hypostasis. The common nature is presented in all the particular hypostases, that is, in separate individuals with all their properties. But the common nature is not all the hypostases (thus, the nature does not perish along with the death of Peter), and the particular hypostases are not predicated to it That is, the individual is not predicated to the nature, or the second essence, in full accordance with the peripatetic logic, otherwise the common nature could be supposed to include into its notion all the individuals under itself. This is also incorrect, as well as to affirm that the individual is the common nature as itself, for all those replacing the notion of "common nature" by that of "particular nature" and thus multiplying it, say nonsense. It is just for those who speak the contrary, that the particular nature is predicated to the individual (p. 6), in other words, "Who declares the particular nature because Peter is nature, as well as Paul, is speaking nonsense. For if the nature is present $(\dot{\varepsilon} \sigma \tau \iota)$ in them, it is one and the same in both of them" (p.12). The anonym, then, points out that by the notion of "particular nature" the opponents simply duplicate both the notion of "common nature" and the names of all the individuals of this nature without exception. At this point of reasoning, he adopts the Platonic position: the general idea could not be divided between the individuals correlating with it by the name. At the same time, he doesn't introduce the standard platonic definition of individuals as similarities participating in the ideas.

As a matter of fact, the author of the treatise meets the classic problem of peripatetic interpretation of Aristotle: how is it possible to cogitate the second essence as presenting in individuals and, correspondingly, how do the singular 
judgments, for ex., "Peter is a human", correlate with the epistemic definition of essence? Within the frame of terminological range of tools of Neo-Platonist commentaries, the anonym fails to reveal clearly the correlation of general, particular and individual in hypostasis. Along with this, the reader is coerced to address constantly the explanations given by the author and the latent context of his original understanding of correlation of common and individual, i. e., to the Chalcedonite notion of trinitary relations in God (pp. 9-10) and especially of the mystery of Christ's embodiment (pp. 2-3, 10).

The anonymous author utilizes the polemical arguments popular in his time and, what is surely possible, by the use of the argument on perdition of species determined by a death of a single individual of that species he tried to turn his opponents' weapon against themselves. His critics of John Philoponus' and tritheists' notion of "particular nature", however, has remained ambiguous and logically incorrect along with that he has caught there, nonetheless, a key Monophysite thesis on difference of particular natures emerging regardless of acceptance of the hypostatic idioms by these natures.

The common (special definitions) is actual just in the particular case of its embodiment for Philoponus, and it is namely for that reason that the death of one human person does not entail the death of all humans. As he notes in the chapter 7 of "Arbiter": "When Paul died no other men did. And when Peter is born and brought into existence, those who are to come after him are not yet in existence. Consequently, each nature may be taken as an essence not in one way alone, but in two. Thus, it is taken in one way when the common basis of a nature is considered in itself as not existing in any one of the individuals, as, for example, the nature of man, of that of the horse. But it is taken in the other way when we take this same common nature as it exists in the individuals and in each of them takes on their individual existence fitting that one individual alone and no other". ${ }^{34}$ This judgment is based on a counter-factual proposition that once the common and the particular in the nature of species are identical and they exist in a similar way, then the death of a single individual of some essence would entail also the death of all the others of the kind, or, which is the same, each species would have only one real representative. Upon that, Philoponus gives out this argument namely in this form bound by hypothetic condition, applying it to the Christological matters: "That the teaching of the Church conceives of natures and hypostases in these ways is evident from the fact that, while we confess one nature of the Father and of the Son and of the

34 John Philoponus. Arbiter, 7; John Damascene, De haeresibus, 83.57-65; ed. Kotter, p. 52; English translation in Saint John of Damascus. Writings, tr. by F.H. Chase, jr. (The Fathers of the Church. A New Translation, 37) [thereafter tr. Chase], New York, 1958, p. 142. 
Holy Ghost, we hold that these have three hypostases, that is to say, persons, by which each one is distinguished from the rest in some peculiar property. For, what might the one nature of the Godhead be but the common basis of the divine nature as considered in itself and conceived as distinct from the peculiar property of each hypostasis? Furthermore, from the fact that we hold a union of two natures in Christ the divine I mean, and the human from this fact it is evident that when we consider the common basis of the nature in each one of the individuals, that is to say, in each one of the hypostases, as being particular and thus not common to any of the others referable to the common species, then we acknowledge the term nature to be more particular. For we certainly do not say that the nature of the Godhead which is understood as being common to the Holy Trinity was incarnate, for in such a case we would be declaring the incarnation of the Holy Ghost. And neither do we hold the common substance of human nature to have been united to God the Word. For thus in the same way the Word of God could rightly be said to have been united both with the men living before His sojourn on earth and with those to come after". 35

Thus, the anonym uses the same argument to criticize the notion of "particular nature" in the very formal sense whereby Philoponus does, arguing on the necessity of the given notion: the identity of common nature and individual would lead to perdition of all the individuals of this nature. The difference is in that the anonym attempts to advocate the Chalcedonite point of view and experiences the lack of resources of peripatetic logic in order to rectify the critics of the notion of "particular nature" by using this argument. On the contrary, John Philoponus consequently adheres to the peripatetic terminology in evolving it through introduction of the concept of "particular nature" and thus comes to heterodox doctrine. For him, the individual idioms of hypostasy are what distinguishes the determined particular nature, that is, a specific case of emergence of the individual belonging to some common nature, from another particular nature belonging to the same common nature.

As for the embodiment of the Word in Christ, it means that the birth of Christ is a connection of the divine Word, that is, one of three particular natures of the unique divine substance, and a particular human nature, which is thought by John Philoponus as emergence of a single hypostasis wherein the "particular nature" of Christ's humanity could be supposed without individual features of real Christ as a human and exists in the hypostasis having accepted these individual features. Along with that, the distinction of divine and human particular natures in the hypostasis of Christ is only speculative, not actual

35 John Philoponus. Arbiter, 7; John Damascene, De haeresibus, 83.68-84; ed. Kotter, p. 52; tr. Chase, pp. 142-143. 
distinction in the existing hypostasis due to that there were no particular nature or hypostasis of Christ as a human prior to connection of particular human nature with the Word. ${ }^{36}$

The probability of acknowledgment of the anonymous author with the works of John Philoponus and the debates deployed around them is also confirmed by the presense of trails of Chalcedonites' polemics against the Trinitary theology of Monophysites and Philoponus in the treatise (p. 9, 10). The last, as known, on the basis of general assumptions of his philosophy - that the substance is the intelligible common and that only particular nature, which accepts its being in hypostasis, is real - has interpreted the commonness of the hypostases of the Trinity as something purely intellectual. ${ }^{37}$ The anonym backs the impossibility to comprehend the Trinity and at the same time neglects the reality of common essential divinity in three Persons without coming to tritheism (p. 9). Further, in the last part of p. 12, he affirms that to introduce the reality different from three divine hypostases means that it should be necessary to cogitate a tetractide of divine ones in God. It is understandable that the anonym's argument is thoroughly improper for Philoponus, but it has been a commonplace in the Chalcedonite milieu. E.g., Eutychius, the Patriarch of Constantinople, promotes it in his treatise "On the Difference between Nature and Hypostasis" (568-577). ${ }^{38}$

Thus, to our mind, the anonymous author of the treatise compiled it in the period when the "Arbiter" of John Philoponus was already published (552) and

36 See: John Philoponus. Arbiter, 7; John Damascene, De haeresibus, 83.1-195; ed. Kotter, pp. 50-55.

37 U.-M. Lang, John Philoponus and controversies over Chalcedon in the six century. A Study and Translation of the "Arbiter", Leuven, 2001, pp. 9-10.

38 Eutychius of Constantinople, De differentiae naturae et personae, 3 ; P. Ananian "L'opusculo di Eutichio patriarca di Costantinopoli sulla 'Distinzione délia natura e persona”, Armeniaca. Mélanges d'études arméniennes. Publiés à l'occasion du 25oe anniversaire de l'entrée des pères mekhitaristes dans l'Ile de Saint-Lazare (1717-1967), Vénise, 1969, pp. 316-382, here 336. In sixth century, the title "Tetradites" become being applied to all doctrines that implied any fourth element in addition to Trinity. E.g., this name was given to the supporters of Damianus, a Monophysite theologian who opposed John Philoponus and who suggested that in the Trinity, only its substance possesses the true reality, whereas the hypostases are just its appearances specified on the account of idioms. A. Grillmeier, T. Hainthaler, Christ in Christian Tradition, vol. 2.4, tr. by O.C. Dean, London, 1996, p. 78. These tetradites should not be confused with Origenist Tetradites (they allegedly added to Trinity Christ's Mind) and the Quartodecimans who were condemned in Can. 95 of the council in Trullo. A. Grillmeier, T. Hainthaler, Christ in Christian Tradition, vol. 2.3, tr. by M. Erhrardt, Oxford, 2013, p. 80. 
the doctrine of tritheism was identified $(557)^{39}$, but the disputation documented in Epilyseis was still actual (the treatise was promulgated in $540-543)^{40}$. Most probably, it is the end of $55^{0}$-s-560-s that this treatise could be better dated. In the following years, the dissociation became more and more evident: the Chalcedonite and Monophysite mindsets have been encapsulated and became impenetrable for each other and reciprocal critics in a maximum degree. As an example of polemics where any vision of the real Monophysites is absence, the treatise of Leontius of Jerusalem "Against the Monophysites" could be taken, having been compiled most probably much later than Leontius of Byzantium's life to whom the authorship of this writing was long ascribed (possibly at the late sixth and early seventh centuries). ${ }^{41}$ Its content witnesses that for Leontius of Jerusalem, the issue of "particular nature" has already been outdated: he just finally elaborates and accomplishes the teaching of Leontius of Byzantium on hypostasis wherein the set of essential and accidental properties of the individualized nature is actualized.

The treatise "On the Common Nature and the Trinity" essentially manifests the same doctrine as the works of Leontius of Byzantium "Against the Nestorians and Eutychians" and "Solution of the Syllogisms of Severus" in a short and simplified version. In particular, the anonymous author does not diversify the usage contexts of the notions of nature and substance, which suggest the variants of their identification and difference, like Leontius of Byzantium does, and, as has been mentioned above, does not express explicitly the thesis on the presence of common nature in hypostasis. We will also note that our treatise is a curious witness of that the intra-Monophysite controversies around tritheism were a vivid matter for the Chalcedonians as well - of course, in the period when these two discourses were compatible with each other.

39 A. Van Roey, "La controverse trithéite jusqu'à l'excommunication de Conon et d'Eugene (557-569)", OLP, 16 (1985), pp. 141-165.

40 D. Evans, Leontius of Byzantium: An Origenist Christology (Dos, 13), Washington, DC, 1970, pp. 2-3.

41 D. Krausmuller, "Leontius of Jerusalem, a theologian of the 7 th century", JTS, $5^{2}$ (2001), pp. 637-657. 